\title{
Theorizing Masculinity in the Context of Luso-Afro-Brazilian Culture
}

\author{
JEREMY LEHNEN \\ University of New Mexico \\ REX P. NIELSON \\ Brigham Young University
}

\begin{abstract}
This special issue of the Journal of Lusophone Studies explores the multifaceted ways that masculinities are performed and embodied throughout the Portuguese-speaking world. The articles presented here interrogate the concept of masculinity to understand better how the arts engage with and participate in rethinking masculinities. While this volume focuses specifically on expressions of masculinity within the Lusophone world, these articles also broadly engage with questions related to masculinities studies by revealing how, within the Portuguese-speaking world, writers are questioning, destabilizing, and in some cases reifying the concept of masculinity.
\end{abstract}

Keywords: Masculinity, gender, hegemony, feminist theory, embodiment

"What is 'masculinity'? [...] I do not claim to have any

definitive answer to this question, but I do have a few proposals [...]" (Halberstam 1)

Reflecting on the origins of masculinities studies, Judith Kegan Gardiner bluntly notes: "Misogyny created feminist theory, and feminist theory has helped create 
masculinity" (36). ${ }^{1}$ This insight points to the profound debt that masculinities studies owes to feminist thought. During the late twentieth century, while seeking to understand, unveil, and ultimately challenge the institutional and social forces that have privileged men and oppressed women, feminist writers and activists drew upon the intersecting fields of cultural studies and poststructuralist thought to establish a theoretical framework that interprets gender and the categories of male and female as social constructions. In other words, feminist theory has reinforced the idea that "masculinity and femininity are loosely defined, historically variable, and interrelated social ascriptions to persons with certain kinds of bodies" (Gardiner 35). Although this framework initially provided insight into the social positions assigned to women, it has likewise revealed the social scripts that govern understandings of men and concepts of masculinities.

An important implication of this theoretical framing is that gender both shapes and is shaped by culture. Accordingly, in the context of the Lusophone world, the study of gender, and masculinity in particular, must necessarily take into account a variety of historical and cultural vicissitudes, including but not limited to the complex histories of conquest and political consolidation of the Iberian Peninsula, global expansion of the Portuguese empire, colonization and slavery, migration and immigration, industrialization, globalization, authoritarian regimes and democratic governance, race and ethnicity, etc. To propose to study Lusophone masculinities is thus to historicize masculinity as a concept and category that evolves over time, but with cultural inflections within the Portuguese-speaking world that make possible comparative analysis. ${ }^{2}$

In their introduction to Lusosex (2002), Susan Quinlan and Fernando Arenas argue that "sexuality and sexual identity are key to the understanding of nationhood and national identity" (xvii), and they outline in broad terms the ways that "sexuality intersects with nationhood and gender identities within

\footnotetext{
${ }^{1}$ While many refer to the study of masculinity as "masculinity studies," we prefer to speak of masculinities in the plural to acknowledge the many and varied forms that masculinity assumes.

2 Susan Quinlan and Fernando Arenas provide a succinct argument for the term Lusophone, explaining: "The term luso now designates 'things' Portuguese or related to the Portuguese language or to Portuguese-speaking cultures (e.g., Luso-Brazilian, Lusophone). We are aware of its possible neocolonial connotations in that it is being used as an umbrella term incorporating former colonizing and colonized nations. From a pragmatic standpoint, however, we believe that no other term is as succinct as lusophone to designate the multiplicity of cultures that we are working with. There are unavoidable paradoxes in working simultaneously with former colonizing powers and the nations that are the result of colonial processes" (xxi).
} 
Portuguese-speaking cultures in the Americas (Brazil), Europe (Portugal), and Africa (Angola and Cape Verde)" (xiv). By examining culturally constructed notions of gender, the essays collected in Lusosex question the "naturalization" of sexuality and gender" (Quinlan and Arenas xv). Severino Albuquerque and Kathryn Bishop-Sanchez adopt a comparable approach in Performing Brazil: Essays on Culture, Identity, and the Performing Arts (2015). While this volume does not exclusively address questions of sexuality or gender, Albuquerque and Bishop-Sanchez approach the study of gender through the frames of cultural studies and performance theory. Bishop-Sanchez in particular argues for understanding culture in terms of "a dialectic between the artificial and the natural, what we do to the world and what the world does to us" (27). This "constructivist dimension" (27) of culture provides a useful way of considering the concept of masculinity: what do we do to masculinity and what does masculinity do to us?

Both Quinlan/Arenas and Albuquerque/Bishop-Sanchez draw heavily from theories of gender performativity. Gender theorists, most notably Judith Butler and Eve Sedgwick, have for a long time endeavored to denaturalize regimes of control imposed upon sexed bodies through hegemonic codings of masculinity and femininity. These scholars have sought to render visible the coercive and sometimes violent ways in which gender finds expression through humans embedded in social relations and networks of power. Similarly, the aim of poststructuralist gender analysis has been to deconstruct long-held binaries (e.g., woman/man, female/male, feminine/masculine) in order to challenge gendered hegemonic power, especially masculinity. In the context of the Lusophone world, scholars interested in gender studies have focused primarily on those most marginalized by hegemonic masculinity, namely women and members of LGBTQ communities.

In the 1990s, many feminist scholars feared that specialists turning their attention to the burgeoning field of masculinity studies would inevitably reinscribe the power, authority, and position of the white male middle-class at the expense of women and minority groups. In Female Masculinity (1998), for example, Jack Halberstam provides an insightful critique of the tendency of many theorists of masculinity to re-center the white male body. Within the last decade, however, critical postures towards masculinity have shifted, and masculinities studies as a discipline has matured to become, as Gardiner notes, 
an independent field invigorated by "queer theory, 'race' studies, and various poststructuralisms as well as by the full range of feminisms" (2). ${ }^{3}$ Scholars in the social sciences and the humanities increasingly recognize the need to understand how hegemonic masculinity affects men, women, and non-binary bodies, and how it contributes to typologies of violence and cycles of domestic abuse.

Four decades ago, Nancy Chodorow defined Western masculinity as emotionally impoverished, competitive, and fearful of intimacy. Such are the well-trafficked stereotypes that mark masculine identity, what Patrick Hopkins refers to as:

the cluster of behaviors and qualities that situate men in relation to women [:] heterosexual prowess, sexual conquest of women, heading a nuclear family, siring children, physical and material competition with other men, independence, behavior autonomy, rationality, strict emotional control, aggressiveness, obsession with success and status, a certain way of walking, a certain way of talking. (98)

Rebecca Biron adds that "public displays of masculinity [include] authoritativeness, defensiveness, aggressiveness, physical strength, selfassurance, or self-reliance as heroic and natural in national formation, military achievement, sport, or business" (11). Biron elsewhere notes the way in which governmental rhetoric "cod[es] active citizenship as male" (1). Chodorow, Hopkins, and Biron define masculinity in Western culture according to this catalogue of behaviors, which likewise find expression in the Lusophone world.

While one might readily acknowledge the harmful and destructive consequences of many of the behaviors that Biron presents, feminists and gender theorists have been most troubled by the way in which these behaviors have become naturalized and systematically institutionalized. This is what gender theorists refer to as hegemonic masculinity. Mike Donaldson explains:

Hegemonic masculinity [...] is exclusive, anxiety-provoking, internally and hierarchically differentiated, brutal, and violent. It is pseudo-natural,

\footnotetext{
${ }^{3}$ For a review of the relationship between "men's studies" and "poststructuralist gender studies," see Bederman.
} 
tough, contradictory, crisis-prone, rich, and socially sustained. While centrally connected with the institutions of male dominance, not all men practice it, though most benefit from it. Although cross-class, it often excludes working-class and black men. [...] Fragile it may be, but it constructs the most dangerous things we live with. (645-46)

"Hegemonic masculinity" thus refers to the naturalized and often invisible relationship between maleness and power. Accordingly, one of the aims of gender and masculinities studies is to challenge masculine stereotypes and bring awareness to non-hegemonic forms of masculinity.

Within the cultures of Portugal, Brazil, Lusophone Africa, and Lusophone Asia, policy makers, mental health practitioners, social scientists, and cultural critics alike urgently need to understand better the negative effects of hegemonic masculinity in order to respond to gendered manifestations of violence, domestic abuse, family crises, sexism, homophobia, transphobia, xenophobia, and racial prejudice. The unique and complex heritage of colonialism, slavery, and industrialization in the Lusophone world has resulted in particular forms of masculinity and gender roles that require further study. In this sense, masculinity serves an important heuristic function, insofar as it allows us, as Bederman explains, "to ask particular types of questions" about gender (15). Indeed, Bederman goes on to argue that "without 'masculinity,' we cannot ask questions about 'maleness' in a time, place, psyche, or text" (15). Despite notable studies on gender in Lusophone settings, including a variety of studies of feminism and women in Brazilian culture, masculinity remains understudied within scholarship on the Lusophone world, particularly literary and cultural studies. ${ }^{4}$

Gary Barker, sociologist and president of the Promundo men's health organization based in Rio de Janeiro, has noted the following regarding masculinity in Brazil: "For the most part, researchers have not adequately studied how men are also subject to the forces of machismo and to stereotyped notions about what is correct behavior for a man" (168). Luiz Valente has also written

\footnotetext{
${ }^{4}$ For an excellent analysis of women and gender in Brazil, see Besse. Quinlan and Arenas note that their volume clearly focuses on the study of homosexuality and other marginalized forms of gender rather than heteronormative masculinity. Most of the essays in their edited volume were written by U.S.-based academics informed by queer theory. For an excellent study on masculinity in Latin America, see Gutmann, although this collection contains only one essay on Brazil, and it focuses exclusively on gay culture.
} 
on the "harmful psychological consequences" of hegemonic masculinity in Brazil, where "men appear as vulnerable [as others] to the ills of the patriarchal order" (12). Such critical observations point to the need for a more complete and critical understanding of the construction of masculinities. They recognize that while men in the Lusophone world enjoy gendered privilege, not all men experience this privilege in the same way or to the same degree; that is, there exists significant heterogeneity within the overarching category of masculinity. Furthermore, these observations underscore the detrimental effects of "toxic masculinity" (defined by psychologists as socially destructive, competitive, violent, homophobic, misogynist, and hyper-masculine) not only on other groups, but also on and between men themselves.

Because of its stable, far-reaching, and naturalized structure, Lusophone hegemonic masculinity remains virtually invisible. An important step in contesting hegemonic masculinity is thus to render it visible, audible, palpable. Halberstam argues that masculinity "becomes legible as masculinity [only] where and when it leaves the white male middle-class body" (2). Kaelin Alexander likewise contends that "masculinity is in fact most apparent from its margins, when it is embodied, practiced, and desired by subjects whose relationship to masculinity mark their performances of it as intriguing, troubling, irrelevant, hyper-stylized, unconvincing, more-than-real, counter-intuitive, or any other emotional shorthand for "mixed up" (1). These marginal expressions of masculinity, variant micro-narratives of gender, would constitute what JeanFrançois Lyotard and Gayatri Chakravorty Spivak call the petits récits that can subvert and challenge the great narratives of hegemonic identity.

For all the factors cited above, this special issue of the Journal of Lusophone Studies on Luso-Masculinities aims to examine Lusophone literary texts and cultural practices that challenge and otherwise resist narratives of hegemonic masculinity. We have organized the special issue into three broad sections.

The first, Masculinity and the Body Politic, opens with Rhian Atkin's essay, "Bodies of War: Disabilities and Heroism in the First World War." Neatly weaving a web of extensive archival evidence, Atkin demonstrates how the disabled bodies of Portugal's war veterans become a proxy for the nation, their wounded frames rendered invisible, overwritten by narratives of masculine heroism at the service of national ideological goals. Subsequently, Mário César Lugarinho, in his essay, "Para além do colonizado e do subalterno: masculinidade 
num poema de Francisco José Tenreiro," pulls the discussion of masculinity and national identity over to the context of Portuguese-speaking Africa. Lugarinho traces the linkages of the binary colonizer/colonized to expressions of hegemonic and non-hegemonic masculinities, which he argues ultimately undergird the relationship of the Estado Novo and to Luso-African national liberation movements. Paying particular attention to the work of Tenreiro, Lugarinho argues that this poet proposes a path of rupture that could allow for the resignification of both autochthonous and colonial legacies in the reformulation of Luso-African masculinities.

Opening the second section, Destabilizing Hegemonic Masculine Codes, Anna-Lisa Halling moves away from the more overt political engagements of Atkin and Lugarinho. In "Upending Hegemonic Masculinity in Soror Maria do Céu's Clavel, y Rosa," Halling demonstrates how Soror Maria's play inverts gender roles and thus both resists and poses a challenge to the period's normative codes of gendered behavior. Kathryn Bishop-Sanchez continues a parallel line of inquiry in her discussion of José Maria Eça de Queirós's Ilustre casa de Ramires. Bishop-Sanchez grounds her analysis in Hélène Cixous's concept of écriture féminine to tease out how Eça's protagonist, Gonçalo Mendes Ramires, employs fiction writing to elevate both his political and social standing, which are dependent upon his irreproachable male virility. At the same time, BishopSanchez shows how Eça's text destabilizes these same claims through humorous plays on the normative codes of gender, sex, and sexuality. Luiz Valente, for his part, traverses the Atlantic to consider the transgressive potential of the erotic in João Guimarães Rosa's fiction. Valente locates the erotic in the work of Guimarães Rosa between law and desire, order and transgression, the masculine and the feminine, and he ultimately argues that the emancipatory potential of the erotic becomes but a waning possibility brought into the service of the status quo.

The articles in the second section frequently hint at homosocial relations and repressed queer potentials within the context of hegemonic masculinity, and this allows for a segue to the third section, Queer Manifestations of Marginal Masculinities. This section veers away from the heterosexual matrix that underpins the first two grouping and delves into the interstices of queer masculinities, opening masculinity to a more ambiguous terrain of performances of gender and sexuality. Israel Pechstein, for his part, forges new pathways in gender and masculinities studies in his consideration of texture in Mário de Sá- 
Carneiro's A confissão de Lúcio. Pechstein queers not only the text but also our reading experience of it. Daniel da Silva continues this exploration of the senses, leading the reader through an auditory journey of the world of fado. Much like the chorus in classic Greek drama, Silva's analysis and discussion of António Variações's work opens new dimensions by revealing the queer presence, potential, and positioning of Variações within the broader fado world. Closing our volume, Lidiana de Moraes examines representations of trans bodies in an overtly masculinist world. In her essay, "Entre metáforas e epifanias: a (trans)formação de identidades em Sérgio Y. vai à América," Moraes takes Armando, Alexandre Vidal Porto's psychiatrist narrator, to task by carefully showing how Vidal Porto makes use of Armando's voice to critique hegemonic masculinity and dominant social mores. According to Moraes, Vidal Porto inverts the traditional gaze that interrogates and many times exoticizes trans bodies to offer an assiduous injunction of heteronormative masculinity and the worldview it promotes.

This special issue of the Journal of Lusophone Studies explores the multifaceted ways in which people throughout the Portuguese-speaking world perform and embody masculinities. The essays within it interrogate masculinity in order to understand better how the arts engage with and participate in a systematic rethinking of masculinities. While our focus is on expressions of masculinity within the Lusophone world, these essays also engage with broader questions related to masculinities studies by revealing how, within the linguistically marked communities of the Portuguese-speaking world, speakers, writers, and readers persistently question, destabilize, and even reify masculinities. Ultimately, in an age of \#timesup, \#metoo, and \#nãoénão, when the conduct of men is receiving heightened critical attention, we hope that this special issue serves to promote gender equality and positive roles for men in society as the articles signal new avenues for research and study.

\section{Works Cited}

Alexander, Kaelin. "Men's Studies: Teaching Masculinities in the Margins." The Good Men Project, 9 March 2011. goodmenproject.com/featured-content/ teaching-masculinities- margins. 
Albuquerque, Severino J., Kathryn Bishop-Sanchez, editors. Performing Brazil: Essays on Culture, Identity, and the Performing Arts. U of Wisconsin P, 2015.

Barker, Gary, Manuel Contreras, Brian Heilman, Ajay Singh, Ravi Verma, and Marcos Nascimento. Evolving Men: Initial Results from the International Men and Gender Equality Survey (IMAGES). International Center for Research on Women (ICRW) and Instituto Promundo, 2011, www.icrw.org/wp-content/uploads/2016/10/ Evolving-Men-Initial-Resultsfrom-the-International-Men-and-Gender-Equality-Survey-IMAGES-1.pdf.

Bederman, Gail. "Why Study 'Masculinity,' Anyway? Perspectives from the Old Days." Culture, Society and Masculinities, vol. 3, no. 1, 2011, pp. 13-25.

Besse, Susan Kent. Restructuring Patriarchy: The Modernization of Gender Inequality in Brazil, 1914-1940. U of North Carolina P, 1996.

Biron, Rebecca E. Murder and Masculinity: Violent Fictions of TwentiethCentury Latin America. Vanderbilt UP, 2000.

Butler, Judith. Gender Trouble: Feminism and the Subversion of Identity. Routledge, 1990.

Chodorow, Nancy. The Reproduction of Mothering. U of California P, 1978.

Connell, Raewyn. Masculinities. 2nd ed., U of California P, 2005.

Donaldson, Mike. "What Is Hegemonic Masculinity?" Theory and Society, vol. 22, no. 5, 1993, pp. 643-57.

Emig, Rainer, and Antony Rowland. Performing Masculinity. Palgrave Macmillan, 2010.

Gardiner, Judith Kegan. Masculinity Studies and Feminist Theory: New Directions. Columbia UP, 2002.

Gutmann, Matthew C., editor. Changing Men and Masculinities in Latin America. Duke UP, 2003.

Halberstam, Judy. Female Masculinity. Duke UP, 1998.

Irigaray, Luce. Key Writings. Continuum, 2004.

Kimmel, Michael S., Jeff Hearn, and Raewyn Connell. Handbook of Studies on Men and Masculinities. Sage, 2005.

Lyotard, Jean-François. The Postmodern Condition. Manchester UP, 1984.

Quinlan, Susan Canty, and Fernando Arenas. Lusosex: Gender and Sexuality in the Portuguese-Speaking World. U of Minnesota P, 2002. 
Sedgwick, Eve Kosofski. Between Men: English Literature and Male Homosocial Desire. Columbia UP, 1985.

Spivak, Gayatri Chakravorty. "Can the Subaltern Speak?" The Post-Colonial Studies Reader, edited by Bill Ashcroft, Gareth Griffiths, and Helen Tiffin, Routledge, 1995, pp. 24-28.

Theweleit, Klaus. Male Fantasies. U of Minnesota P, 1987.

Valente, Luiz Fernando. "Machado’s Wounded Males.” Hispania, vol. 84, no. 1, 2001, pp. 11-19. 